\title{
Arbeid in publieke en private sectoren vergeleken
}

\author{
Peter Smulders \& Irene Houtman ${ }^{*}$
}

In de media is de laatste jaren regelmatig melding gemaakt van arbeidsproblemen en sociale onrust in de publieke sectoren. Recent onderzoek brengt de kwaliteit van de arbeid in de publieke sectoren echter slechts mager in beeld. Doel van dit artikel is daarom de kwaliteit van de arbeid van de publieke sectoren in Nederland in vergelijking tot de private sectoren in maat en getal weer te geven. De in dit artikel te gebruiken data zijn afkomstig van de door TNO en CBS in 2010 uitgevoerde Nationale Enquête Arbeidsomstandigheden (NEA), met een omvangrijke en representatieve respons van ruim 23.000 werknemers.

Uit de analyses - die zich richten op de vergelijking van 10 private en 10 publieke sectoren - blijkt overduidelijk dat de mentaal-emotionele belasting in de publieke sectoren over de hele linie groter is dan in de private sectoren. Daarentegen komen fysieke belasting, gevaarlijk werk en afwijkende werktijden significant minder voor in de publieke sectoren. In de publieke sectoren wordt ook meer met vaste contracten gewerkt en is de duur van de werkweek korter. Arbeidsonzekerheid komt meer dan gemiddeld voor in de financiële en zakelijke dienstverlening en het vervoer, maar ook bij de ministeries, justitie en politie. Gevoelens van burn-out komen veruit het meest voor in de drie onderwijssectoren. De salaristevredenheid is het grootst in de financiële dienstverlening, het hoger onderwijs en de ministeries. Bij de politie en in de horeca is de salaristevredenheid het laagst. De arbeidstevredenheid is gemiddeld het hoogst in de publieke sectoren.

Publieke sectoren en private sectoren kunnen ieder voor zich moeilijk als één geheel worden gezien. Ministeries, gemeenten \& provincies en hoger onderwijs lijken namelijk - wat arbeidsvoorwaarden en arbeidsomstandigheden betreft - sterk op de zakelijke en financiële dienstverlening. Maar basis- en voortgezet onderwijs, zorg \& welzijn en politie verschillen sterk van de andere genoemde publieke sectoren.

\section{Inleiding}

Doel van dit artikel is om een beeld te schetsen van de kwaliteit van de arbeid van de publieke sectoren in Nederland in vergelijking met de private sectoren. Bij de definitie van de kwaliteit van de arbeid wordt vaak uit gegaan van de vier A's:

* Peter G.W. Smulders is werkzaam bij TNO Work \& Health, Hoofddorp, e-mailadres: peter.smulders@tno.nl. Irene L.D. Houtman is werkzaam bij TNO Work \& Health, Hoofddorp. 
Arbeidsinhoud en -organisatie, Arbeidsomstandigheden, Arbeidsverhoudingen en Arbeidsvoorwaarden (bijv. Houtman, Smulders \& Klein Hesselink, 2004). Ook andere benaderingen zijn in omloop, zoals op basis van Psychosociale factoren, Ergonomische factoren, Arbeidscontract en Werktijden (Houtman \& Van den Bossche, 2010). Om enige toespitsing aan te brengen in de in dit artikel te belichten aspecten van de kwaliteit van de arbeid wordt de onderzoeksliteratuur op dit gebied langs gelopen. Een conclusie daarbij is dat het onderzoek de kwaliteit van de arbeid in de publieke sectoren in verhouding tot de private sectoren slechts mager in beeld heeft gebracht. Er is gepubliceerd over afzonderlijke sectoren in het publieke domein - in het bijzonder de zorg, het onderwijs en de politie (bijv. Dagevos, 1995; Den Besten, Blatter \& Smulders, 2009; Freese, Heinen \& Schalk, 1999; Moree \& Vulto, 1995) - maar heel weinig over publieke en private bedrijfssectoren in vergelijkende zin.

Het laatste type onderzoeksliteratuur overziend valt het op dat relatief veel aandacht gericht is op thema's als waarden die in de publieke en de private sector toegekend worden aan het werk (Lyons, Duxbury \& Higgins, 2006; Midttun, 2007; Van der Wal \& Huberts, 2008; Van der Wal, De Graaf \& Lasthuizen, 2008; Willem, De Vos \& Buelens, 2010), werkmotivatie (Buelens \& Van den Broeck, 2007; Steijn, 2008; Steijn \& Groeneveld, 2009) en betrokkenheid bij het werk (Lyons, Duxbury \& Higgins, 2006; Zeffane, 1994). Boyne, Jenkins en Poole (1999) karakteriseerden de werkmotivatie en betrokkenheid in de publieke sector als een 'public sector ethos', gedefinieerd met principes als loyaliteit, eerlijkheid, het dienen van de samenleving en het hoog houden van politieke neutraliteit. Daarnaast is beloning een terugkerend thema (Allington \& Morgan, 2003; Elliott \& Murphy, 1987; Miller, 1996; Van der Hoek, 1989). Deze studies betreffen verschillende perioden en verschillende landen (de VS, Groot Brittannië en Nederland). Uit deze onderzoeken blijkt dat uitkomsten van loonvergelijkingen tussen de private en publieke sector sterk afhankelijk zijn van tijdsperioden, van loon- en beroepsgroepen binnen betreffende sectoren en van wat wel en niet meegerekend wordt bij het inkomen. De effecten van de (personele) kostenbesparingen bij de overheid in de periode 1984-2009 op de kwaliteit van de arbeid en de productiviteit werden belicht door Dhondt, Ten Have en Kraan (2010). Zij konden, tegen hun verwachtingen in, geen effect vaststellen van kostenbesparingen op veranderingen in autonomie in het werk en het niveau van het werk. Een vergelijking met de private sector maakten deze auteurs niet. Ten slotte zijn werkstress (Dollard \& Walsh, 1999; Macklin, Smith \& Dollard, 2006) en arbeidssatisfactie (Aryee, 1992; DeSantis \& Durst, 1996; Ghinetti, 2007; Pillay, 2009; Steijn \& Groeneveld, 2009) kleine thema's op vergelijkend gebied. Dollard en Walsh (1999) vonden dat verzuim door stress in de publieke sector vaker voorkomt dan in de private sector. Macklin et al. (2006) concludeerden dat een aantal werkaspecten (werkdruk, ondersteuning door leiding en collega's, stress en arbeidssatisfactie) in de publieke sector als geheel niet significant verschilden van die in de private sectoren, althans in Australië. Wel was de autonomie in het werk in de publieke sector hoger dan in de private sector.

DeSantis en Durst (1996) konden - op basis van grote steekproeven - voor de Verenigde Staten concluderen dat de arbeidssatisfactie in de publieke sector gro- 
ter was dan in de private sector. Op basis van Italiaanse surveydata concludeerde Ghinetti (2007) ook dat publieke werknemers tevredener zijn dan private werknemers als het gaat om zekerheid, collega's en veiligheid en gezondheid. Maar voor Singapore vond Aryee (1992) dat de kwaliteit van het werk voor 'professionals' in de private sector gemiddeld beter is dan voor hun counterparts in de publieke sector. Pillay (2009) concentreerde zich op verpleegkundigen in ZuidAfrika, en vond eveneens dat die in de private sector gemiddeld tevredener waren dan in de publieke sector.

Steijn en Groeneveld (2009) gebruikten de zogenaamde POMO (Personeels- en Mobiliteitsonderzoeken)-data van het ministerie van BZK uit de jaren 2001, 2004 en 2008 om de arbeidstevredenheid van een aantal publieke sectoren in kaart te brengen en die te vergelijken met de private sector als geheel. Op basis van de 2008-data concluderen deze auteurs (pp. 182-183) dat er geen substantieel verschil in arbeidstevredenheid is tussen het publieke en het private domein. Binnen het publieke domein was de arbeidstevredenheid het hoogst bij de rechterlijke macht, onderzoeksinstellingen, waterschappen, provincies en gemeenten en het laagst bij defensie en politie.

In de kranten en weekbladen is de laatste jaren regelmatig melding gemaakt van arbeidsproblemen en sociale onrust in de zorg, het onderwijs, de politie, de ministeries, kortom bij diverse delen van de publieke sector.

- Werkdruk, maar ook werkstress en burn-out zijn in de discussie vaak terugkerende thema's. Te lange werktijden en overwerk zouden daar debet aan zijn.

- In bijvoorbeeld het onderwijs en bij de politie kan men klachten tegenkomen over de hoge administratieve druk. Dat gaat zelfs zover dat gesproken wordt van het aantasten van de 'beroepseer', met name in het onderwijs.

- In enkele van de publieke sectoren is sprake van intimidatie en agressie door patiënten, passagiers of leerlingen, kortom klanten en/of publiek. Deze berichten komen uit de gezondheidszorg, het onderwijs, het openbaar vervoer en de politie.

- Sinds de financiële crisis van 2008 spelen personele bezuinigingen een rol en daarmee toegenomen arbeidsonzekerheid. In het onderwijs en de zorg heeft dit geleid tot stakingen.

- Ten slotte gaat het om klachten over het achterblijven van de inkomens in vergelijking tot de private sector.

Dit zijn enkele thema's uit het sociaaleconomische nieuws van de laatste paar jaren.

Duidelijk is welke werkkenmerken in onderzoek en de pers nogal eens onder de loep liggen als het gaat om vergelijkingen tussen de private en de publieke sectoren. Hierbij dient te worden aangetekend dat deze werkkenmerken vooral aan de orde komen in krantenberichten en deels in buitenlands onderzoek. Er is een groot gebrek aan enigszins betrouwbaar Nederlands peer-reviewed onderzoek. Gezien de in eerder onderzoek en de in de pers genoemde aspecten worden in deze studie in ieder geval de volgende werkkenmerken betrokken: werkdruk en gevoelens van burn-out, administratieve druk, intimidatie en agressie door klan- 
ten, flexibele contracten, te lange werktijden en gebrek aan autonomie in het werk, werkonzekerheid, alsmede 'effectvariabelen' als loon- en arbeidssatisfactie. Daarnaast zullen nog enige werkkenmerken in de analyses worden betrokken die met genoemde kenmerken gerelateerd zijn. Men denke hierbij aan de werkinhoud en de fysieke arbeidsbelasting.

Het onderzoek dat hier wordt gerapporteerd, is derhalve vooral van exploratief karakter.

\section{Methode}

De in dit artikel te gebruiken data zijn afkomstig van de door TNO en CBS sinds 2005 jaarlijks uitgevoerde Nationale Enquête Arbeidsomstandigheden (NEA), met een representatieve respons van 22.000-24.000 werknemers per jaar. De steekproef wordt door het CBS getrokken uit het Banenbestand en sinds 2008 uit de Polisadministratie (een gegevensregister van alle inkomensverhoudingen in Nederland, eigendom van het UWV, met het CBS als medegebruiker). Voor de vorming van het onderzoeksbestand van de Nationale Enquête Arbeidsomstandigheden waren geslacht, leeftijdsklasse, bedrijfsklasse en regionaal gebied de steekproefkenmerken. Er werd niet geselecteerd op aantal werkuren; dus ook personen met een 'klein baantje' - van minder dan 12 uur, vaak uitgeoefend door studenten, scholieren en moeders met kinderen thuis - komen in de NEA-steekproef voor. Details over de omvang, representativiteit en betrouwbaarheid van de NEA zijn beschreven door Koppes et al. (2011). Voor het beantwoorden van de onderzoeksvragen zijn alleen data uit het recente jaar 2010 gebruikt. Dat jaar omvatte de uiteindelijke steekproef 23.266 werknemers in loondienst (zie tabel 1).

De in dit artikel te rapporteren analyses betreffen de vraag hoe belangrijke private en publieke bedrijfssectoren scoren op kenmerken van het werk. In de NEAvragenlijst wordt aan de werknemers gevraagd in welke bedrijfssector men werkzaam is. De vragenlijst biedt daarvoor 41 met name genoemde sectoren aan. Om de sector-vergelijking hier niet te gedetailleerd te laten worden, zijn sommige van de 41 sectoren voor onze analyses samengenomen. Zo zijn bijvoorbeeld de industriesectoren samengenomen tot één sector industrie. Hetzelfde is gebeurd bij de bouwsectoren, de handelssectoren, de sectoren in de zakelijke dienstverlening, et cetera. De sectoren in de publieke sector, vermeld in de vragenlijst, staan ook opgesomd in tabel 1. Ze zijn in dit artikel niet samengevoegd, maar zo veel mogelijk apart gehouden. Uiteindelijk leiden deze samenvoegingen tot 20 sectoren, waarvan 10 private en 10 publieke sectoren.

Hoewel door sommigen misschien nog nadere detaillering gewenst ware, omvat onze indeling alle grote publieke en private sectoren. Als aparte entiteit in het databestand ontbreken defensie, brandweer, waterschappen, zelfstandige bestuursorganen, et cetera; deze eenheden vormden geen onderdeel van de 41 in de vragenlijst vermelde sectoren. Bij de indeling van de sectoren in de tweedeling publiek-privaat zijn kanttekeningen te plaatsen. Sectoren als het vervoer, de zorg, 
Tabel 1 Steekproefsamenstelling alsmede enkele sekse-, leeftijds- en opleidingskenmerken van de 20 sectoren (bron: NEA 2010)

\begin{tabular}{|c|c|c|c|c|c|c|}
\hline & Sectoren & $\mathbf{N}$ & $\%$ & $\begin{array}{l}\% \\
\text { vrouwen }\end{array}$ & $\begin{array}{l}\% \text { I5-24 } \\
\text { jarigen }\end{array}$ & $\begin{array}{l}\text { \% hoger } \\
\text { opgeleiden } \\
\text { (hbo-wo) }\end{array}$ \\
\hline I & Industrie & 3060 & 13,2 & 21,3 & 11,3 & 22,4 \\
\hline 2 & Bouw & 1182 & 5,1 & 11,9 & 14,9 & 13,3 \\
\hline 3 & Handel & 2703 & 11,6 & 49,8 & 33,8 & 11,2 \\
\hline 4 & Vervoer \& communicatie & 1135 & 4,9 & 23,3 & 12,9 & 15,7 \\
\hline 5 & Financiële instellingen & 985 & 4,2 & 48,6 & 5,8 & 47,9 \\
\hline 6 & Zakelijke dienstverlening & 2061 & 8,9 & 37,0 & 6,2 & 58,8 \\
\hline 7 & Cultuur, sport, recreatie, etc. & 575 & 2,5 & 54,6 & 14,9 & 37,1 \\
\hline 8 & Landbouw, bosbouw, visserij & 391 & $\mathrm{I}, 7$ & 22,0 & 23,0 & 13,1 \\
\hline 9 & Horeca & 918 & 3,9 & 50,3 & 49,7 & 9,5 \\
\hline \multirow{2}{*}{10} & Energie, water \& overige bedrijven & 2665 & $\mathrm{II}, 5$ & 45,8 & 16,3 & 21,6 \\
\hline & Totaal private sector & 15.676 & 67,4 & 36,5 & 18,0 & 25,1 \\
\hline 11 & Basis- \& speciaal onderwijs & 627 & 2,7 & 77,4 & 5,4 & 77,9 \\
\hline 12 & Voortgezet onderwijs & 456 & 2,0 & 52,0 & 3,9 & 73,4 \\
\hline 13 & Hoger onderwijs & 323 & $\mathrm{I}, 4$ & 49,4 & 5,0 & 78,4 \\
\hline 14 & Ziekenhuizen etc. & 2067 & 8,9 & 79,2 & 10,0 & 42,3 \\
\hline 15 & Verpleeg- en verzorgingshuizen etc. & 2010 & 8,6 & 86,6 & 16,4 & 22,2 \\
\hline 16 & Gemeenten \& provincies & 748 & 3,2 & 44,3 & 1,6 & 50,6 \\
\hline 17 & Ministeries & 345 & $\mathrm{I}, 5$ & 35,9 & 4,3 & $4 I, 6$ \\
\hline 18 & Justitie, excl. ministerie & 140 & 0,6 & 54,3 & 2,1 & 53,6 \\
\hline 19 & Politie & 222 & 1,0 & 30,2 & $\mathrm{II}, 3$ & 14,0 \\
\hline \multirow[t]{3}{*}{20} & Rest publieke sector & 654 & 2,8 & 46,3 & 8,1 & 51,0 \\
\hline & Totaal publieke sector & 7.591 & 32,6 & 68,0 & 9,4 & 44,3 \\
\hline & Totaal & 23.266 & 100,0 & 46,8 & 15,2 & 31,4 \\
\hline
\end{tabular}

het onderwijs, cultuur, sport \& recreatie kennen zowel publieke als private onderdelen of kenmerken. Er is voor gekozen om de sectoren met waarschijnlijk het grootste accent in privaat of publiek aldaar ook onder te brengen. De categorie 'Rest publieke sector' (tabel 1 onderaan) bestaat uit werknemers werkzaam bij sociale verzekeringen, de sociale werkvoorziening, banenpools, beveiliging, defensie, opleidingscentra, kinderopvang, et cetera.

Zoals tabel 1 laat zien, is $67,4 \%$ van de werknemers in de steekproef werkzaam in de private en bijna 33\% in de publieke sectoren. In tabel 1 zijn tevens sekse-, leeftijds- en opleidingskarakteristieken van de diverse sectoren vermeld. Te zien valt dat het publieke domein voor $68 \%$ uit vrouwen bestaat en het private domein slechts voor $36,5 \%$. De bouw, de landbouw en de industrie zijn typische mannensectoren; het onderwijs en de zorg typische vrouwensectoren. Wat betreft de leef- 
tijd omvat het private domein twee maal zoveel jongeren (15-24 jaar) als het publieke domein (18\% versus $9 \%$ ). Horeca en handel zijn met name sectoren met veel jongeren. Ten slotte herbergt het publieke domein $44 \%$ hoger opgeleiden (hbo en wo), terwijl dit percentage in het private domein slechts 25 is. Sectoren met veel hoger opgeleiden zijn de drie onderwijssectoren, ministeries, gemeenten \& provincies, justitie en de financiële en zakelijke dienstverlening. In deze steekproef bleek $80 \%$ werknemer te zijn met een vast contract. Bijna $8 \%$ was werknemer in tijdelijke dienst met uitzicht op een vast contract. De rest (12\%) was werknemer met een tijdelijk contract of was uitzendkracht, oproepkracht of invalkracht.

Om de onderzoeksvragen te kunnen beantwoorden zijn 18 werkkenmerken (inclusief vier zogenaamde effect-kenmerken) uit de NEA-vragenlijst geselecteerd (zie tabel 2). Deze kenmerken sluiten aan bij de vermelde onderzoeksliteratuur en bij discussies die in kranten en tijdschriften gevoerd zijn over de positie van de werknemers in de publieke sector versus die in de private sector wat betreft hun arbeidvoorwaarden en arbeidsomstandigheden. De meeste van deze werkkenmerken zijn weer samengesteld uit twee of meer vragenlijstitems. Andere bestonden uit één item, zoals contractvorm, aantal werkuren per week, arbeids- en salaristevredenheid. Tabel 2 geeft de betrouwbaarheidscoëfficiënt Cronbach's alpha en de gemiddelde waarde per werkkenmerk. De betrouwbaarheidscoëfficiënten alpha zijn over het algemeen voldoende hoog. Het werkkenmerk 'inkrimping bedrijf bestaat uit het gemiddelde van twee onderliggende items (vragen) die onderling niet correleren ('Is uw bedrijf het laatste jaar ingekrompen met gedwongen ontslagen resp. zonder gedwongen ontslagen?' met ja-nee als antwoordmogelijkheden). Er is voor gekozen om deze twee vragen toch tot één werkkenmerk samen te voegen omdat ze theoretisch bij elkaar horen. Ze vullen elkaar immers aan. De 18 geselecteerde werkkenmerken kunnen door middel van factoranalyse (Principale Componenten Analyse met Varimax-rotatie) gereduceerd worden tot vijf thema's, namelijk (tabel 3):

1 de mentale werkbelasting (gevarieerd en lerend werk, cognitief zwaar werk, werkdruk, administratieve druk, emotioneel zwaar werk, intimidatie en agressie);

2 de fysieke werkbelasting (zwaar en gevaarlijk werk, ook afwijkende werktijden);

3 het arbeidscontract, de werktijden en autonomie in het werk;

4 bedrijfsinkrimping en werkonzekerheid;

5 de effectkant van het werk (gevoelens van burn-out, vertrekwens; salaris- en arbeidstevredenheid).

De resultaten van factoranalyse zullen worden gebruikt om de rest van dit artikel te structureren.

Eerder in dit artikel werd vermeld dat in onderzoek naar arbeid nogal eens wordt uitgegaan van de zogenaamde vier A's (Arbeidsinhoud en -organisatie, Arbeidsomstandigheden, Arbeidsverhoudingen en Arbeidsvoorwaarden). De operationa- 
Tabel 2 Statistische aspecten van de 18 werkkenmerken (inclusief de vier zogenaamde effectkenmerken) in de analyse ( $n=20.638$; bron: NEA 2010)

\begin{tabular}{llll}
\hline & Alpha & Gemiddelde \\
\hline Gevarieerd, creatief \& lerend werk (3 items; nooit-altijd, I-3) & 0,77 & 2,06 \\
Cognitief zwaar werk (3 items; nooit-altijd, I-3) & 0,8 I & 2,05 \\
Werkdruk: snel, hard, veel werken \& hectiek (4 items; nooit-altijd, I-3) & 0,86 & I,64 \\
Werk belemmerd door administratie (I item; nooit-dagelijks, I-4) & nvt & I,55 \\
Emotioneel zwaar werk (3 items; nooit-vaak/altijd, I-3) & 0,83 & I,66 \\
Intimidatie, agressie, pesten door klanten (4 items; nooit-vaker, 0-I) & 0,67 & 0,23 \\
Fysiek zwaar werk (3 items; nee-soms-regelmatig, I-3) & 0,76 & I,45 \\
Gevaarlijk werk (I item; nee-soms-regelmatig, I-3) & $n v t$ & I,28 \\
Afwijkende werktijden (3 items; nee-soms-regelmatig, I-3) & 0,78 & I,63 \\
Contractvorm (I item; vast vs. 0-I) & $\mathrm{nvt}$ & 0,12 \\
Aantal contracturen per week (I item; aantal contracturen per week) & $\mathrm{nvt}$ & 30,6 \\
Autonomie (4 items; nee-soms-meestal, I-3) & 0,79 & 2,49 \\
Inkrimping bedrijf (2 items; niet-wel, 0-I) & $\mathrm{r}=0,02$ & 0,23 \\
Werkonzekerheid (2 items; nee, 0-I) & $\mathrm{r}=0,56$ & 0,29 \\
Gevoelens van burn-out (5 items; nooit-dagelijks, I-7) & 0,86 & 2,04 \\
Vertrekwens (3 items; nee-ja, 0-I) & 0,65 & 0,34 \\
Salaristevredenheid (I item; niet tevreden, heel tevreden, I-3) & $\mathrm{nvt}$ & $\mathrm{I}, 92$ \\
Arbeidstevredenheid (I item; ontevreden-tevreden, I-5) & $\mathrm{nvt}$ & 3,84 \\
\hline
\end{tabular}

lisering van deze vier A's in concretere begrippen is slechts ten dele mogelijk. De 'vertaling' van de hierboven vermelde vijf thema's in deze vier A's is niet evident. Arbeidsinhoud en -organisatie en arbeidsomstandigheden overlappen elkaar namelijk ten dele. En vormen van werkbelasting - de eerste twee hierboven geidentificeerde thema's - zijn zowel onder arbeidsomstandigheden als onder arbeidsinhoud en -organisatie te plaatsen. Werkkenmerken als het arbeidscontract en de werktijden zijn onder de arbeidsvoorwaarden te plaatsen. Werkzekerheid is wellicht ook op te vatten als een arbeidsvoorwaarde. En ten slotte vallen de vier 'effectkenmerken' (tevredenheid, vertrekwens en gevoelens van burn-out) strikt genomen niet onder de vier A's.

Achtereenvolgens geven we in de resultatensectie van dit artikel het volgende weer:

1 de gemiddelde scores van alle 20 sectoren op de 18 werkkenmerken, om te laten zien welke sectoren hoog of laag scoren op betreffende kenmerk;

2 de plaats van de 20 sectoren in een tweedimensionale figuur, dus op een horizontale en een verticale as; deze vorm van comprimering vindt plaats door gebruikmaking van factorscores en heeft tot doel om op elkaar lijkende sectoren op te sporen (meer details over de methode volgen verderop); 
Tabel 3 Resultaat van een factoranalyse op de 18 werkkenmerken (met minimale Eigenwaarde = 1 en na Varimax-rotatie, $n=20.638$; bron: NEA 2010; ladingen < ,250 weggelaten)

\begin{tabular}{|c|c|c|c|c|c|}
\hline & I & 2 & 3 & 4 & 5 \\
\hline Gevarieerd, creatief \& lerend werk (nooit-altijd, I-3) & ,487 & & & & ,491 \\
\hline Cognitief zwaar werk: (nooit-altijd, I-3) & ,637 & & & & \\
\hline Werkdruk: snel, hard, veel werken \& hectiek (nooit-altijd, I-3) & ,650 & & & & \\
\hline $\begin{array}{l}\text { Werk belemmerd door onnodige administratie (nooit-dagelijks, } \\
\text { I-4) }\end{array}$ &, 541 & & & & \\
\hline Emotioneel zwaar werk (nooit-vaak/altijd, I-3) & ,728 & & & & \\
\hline Intimidatie, agressie, pesten door klanten (nooit-vaker, $0-I$ ) & ,450 & &,- 357 & & \\
\hline Fysiek zwaar werk (nee-soms-regelmatig, I-3) & & ,791 & & & \\
\hline Gevaarlijk werk (nee-soms-regelmatig, I-3) & & ,807 & & & \\
\hline Afwijkende werktijden (weekend; nee-soms-regelmatig, I-3) & &, 526 &,- 376 & & \\
\hline Contractvorm (vast vs. tijdelijk, $0-I$ ) & & &,- 706 & ,254 & \\
\hline Aantal contracturen per week (aantal contracturen per week) & & & ,737 & & \\
\hline Autonomie (nee-soms-meestal, I-3) & &,- 282 & ,475 & & ,285 \\
\hline Inkrimping bedrijf (niet-wel, $0-I$ ) & & & & ,634 & \\
\hline Werkonzekerheid (nee-ja, 0-I) & & & & ,759 & \\
\hline Gevoelens van burn-out (nooit-dagelijks, I-7) & ,477 & & & &,- 546 \\
\hline Vertrekwens (nee-ja, $0-I$ ) & & & & &,- 535 \\
\hline Salaristevredenheid (niet tevreden, heel tevreden, I-3) & & & & &, 558 \\
\hline Arbeidstevredenheid (ontevreden-tevreden, I-5) & & & & & ,737 \\
\hline
\end{tabular}

3 een zogenaamd werkkenmerkenprofiel van de publieke sector als geheel - op basis van z-scores - om te laten zien waar de publieke sector als geheel hoog resp. laag op scoort, in vergelijking met de private sector als geheel.

Alvorens over te gaan tot het rapporteren van de resultaten is nog een methodische opmerking op zijn plaats. Het moge duidelijk zijn dat er tussen de 20 te onderzoeken sectoren soms substantiële verschillen zijn in de samenstelling voor wat betreft sekse, leeftijd, opleiding en etniciteit. Zoals vaker is aangetoond, laten onze data ook zien dat de beroepen in de gezondheids- en welzijnszorg en in het basisonderwijs typische 'vrouwenberoepen' zijn, en die in de bouw, de landbouw en de industrie typische 'mannenberoepen'. Daarnaast zijn de werknemers in het onderwijs en bij de centrale overheid gemiddeld significant ouder en beter opgeleid dan in de handel en de horeca. Of daarvoor gecontroleerd moet worden, is de vraag. We hebben ervoor gekozen om dat niet te doen, omdat het de bedoeling van de analyses in dit artikel is om de verschillen tussen de publieke en private sectoren te beschrijven 'zoals ze zijn'. Als er gecontroleerd zou worden voor demografische factoren als sekse, leeftijd, opleiding en etniciteit, wordt het onduidelijk wat de vergelijking tussen de sectoren precies voorstelt. 


\section{Resultaten}

Eerst wordt de mentale belasting in de publieke resp. de private sectoren onder de loep genomen. Onder de mentale belasting vallen volgens de uitgevoerde factoranalyse zes werkkenmerken, waaronder gevarieerd, creatief en lerend werk. De zes werkkenmerken lijken een mentaal-emotioneel belastende kant gemeen te hebben.

Tabel 4a Gemiddelde scores van de 20 sectoren op mentale belastingaspecten $(n=20.638)$

\begin{tabular}{|c|c|c|c|c|c|c|}
\hline $\begin{array}{l}\text { Bedrijfs- } \\
\text { sectoren }\end{array}$ & $\begin{array}{l}\text { Gevari- } \\
\text { eerd, } \\
\text { creatief \& } \\
\text { lerend } \\
\text { werk, } \\
\text { nooit-altijd } \\
(\mathrm{I}-3)\end{array}$ & $\begin{array}{l}\text { Cognitief } \\
\text { zwaar } \\
\text { werk: con- } \\
\text { centratie } \\
\text { \& naden- } \\
\text { ken nodig, } \\
\text { nooit- } \\
\text { altijd (I-3) }\end{array}$ & $\begin{array}{l}\text { Werk- } \\
\text { druk, } \\
\text { nooit- } \\
\text { altijd } \\
(I-3)\end{array}$ & $\begin{array}{l}\text { Werk } \\
\text { belem- } \\
\text { merd } \\
\text { door } \\
\text { onnodige } \\
\text { admini- } \\
\text { stratie, } \\
\text { nooit- } \\
\text { dageliiks } \\
(1-4)\end{array}$ & $\begin{array}{l}\text { Emotio- } \\
\text { neel } \\
\text { zwaar } \\
\text { werk, } \\
\text { nooit- } \\
\text { vaak/ } \\
\text { altijd } \\
(I-3)\end{array}$ & $\begin{array}{l}\text { Intimida } \\
\text { tie, agre } \\
\text { sie, pes- } \\
\text { ten door } \\
\text { klanten, } \\
\text { nooit-ee } \\
\text { enkele } \\
\text { keer of } \\
\text { vaker } \\
(0-1)\end{array}$ \\
\hline \multicolumn{7}{|l|}{ Privaat } \\
\hline Industrie & 2,01 & 2,05 & $|, 6|$ & $\mathrm{I}, 57$ & $\mathrm{I}, 49 \square$ & $0,09 \square$ \\
\hline Bouw & 2,13 & 2,03 & $\mathrm{I}, 58 \square$ & 1,37 & $\mathrm{I}, 44 \square$ & $0,11 \square$ \\
\hline Handel & $\mathrm{I}, 87 \square$ & $\mathrm{I}, 80 \square$ & $\mathrm{I}, 58 \square$ & $\mathrm{I}, 3 \mathrm{I} \square$ & $\mathrm{I}, 44 \square$ & 0,26 \\
\hline $\begin{array}{l}\text { Vervoer \& } \\
\text { communicatie }\end{array}$ & $\mathrm{I}, 88 \square$ & 2,09 & 1,62 & $\mathrm{I}, 49$ & 1,57 & 0,27 \\
\hline $\begin{array}{l}\text { Financiële } \\
\text { instellingen }\end{array}$ & 2,14 & $2,30 \Delta$ & I,74 $\Delta$ & $1,80 \wedge$ & $\mathrm{I}, 63$ & 0,16 \\
\hline $\begin{array}{l}\text { Zakelijke } \\
\text { dienstverlening }\end{array}$ & $2,20 \boldsymbol{\Delta}$ & $2,29 \boldsymbol{\Delta}$ & $1,74 \boldsymbol{\Delta}$ & 1,67 & 1,65 & 0,14 \\
\hline $\begin{array}{l}\text { Cultuur, sport, } \\
\text { recreatie, etc. }\end{array}$ & 2,12 & 1,94 & I,63 $\Delta$ & $\mathrm{I}, 42$ & $\mathrm{I}, 64$ & 0,24 \\
\hline $\begin{array}{l}\text { Landbouw, } \\
\text { bosbouw, visserij }\end{array}$ & $\mathrm{I}, 87 \square$ & $\mathrm{I}, 80 \square$ & I,46 $\square$ & $\mathrm{I}, 26 \square$ & I,39 ㅁ & $0,06 \square$ \\
\hline Horeca & $\mathrm{I}, 79 \square$ & $\mathrm{I}, 70 \square$ & $1,77 \boldsymbol{\Lambda}$ & $\mathrm{I}, 17 \square$ & $\mathrm{I}, 46 \square$ & 0,28 \\
\hline $\begin{array}{l}\text { Energie, water } \\
\text { etc. }\end{array}$ & 1,97 & 1,94 & I,59 ᄆ & $\mathrm{I}, 4 \mathrm{I}$ & 1,54 & 0,17 \\
\hline \multicolumn{7}{|l|}{ Publiek } \\
\hline $\begin{array}{l}\text { Basis- \& speciaal } \\
\text { onderwijs }\end{array}$ & $2,50 \Delta$ & $2,32 \Delta$ & I,77 $\Delta$ & $1,96 \Delta$ & $2,11 \boldsymbol{\Delta}$ & 0,27 \\
\hline $\begin{array}{l}\text { Voortgezet } \\
\text { onderwijs }\end{array}$ & $2,23 \Delta$ & $2,29 \Delta$ & $1,70 \Delta$ & $1,80 \Delta$ & $2,06 \Delta$ & 0,35 \\
\hline Hoger onderwijs & $2,29 \boldsymbol{\Delta}$ & $2,34 \Delta$ & I,72 $\Delta$ & $\mathrm{I}, 77$ & $\mathrm{I}, 78$ & $0,12 \square$ \\
\hline Ziekenhuizen etc. & $2,17 \Delta$ & 2,22 & $1,68 \Delta$ & $\mathrm{I}, 73$ & $2,01 \Delta$ & $0,43 \boldsymbol{\Delta}$ \\
\hline $\begin{array}{l}\text { Verpleeg- en } \\
\text { verzorgingshuizen }\end{array}$ & 2,09 & 1,98 & $|, 6|$ & 1,53 & I,97 $\Delta$ & $0,42 \boldsymbol{\Delta}$ \\
\hline
\end{tabular}


Tabel 4a (Vervolg)

\begin{tabular}{|c|c|c|c|c|c|c|}
\hline $\begin{array}{l}\text { Bedrijfs- } \\
\text { sectoren }\end{array}$ & $\begin{array}{l}\text { Gevari- } \\
\text { eerd, } \\
\text { creatief \& } \\
\text { lerend } \\
\text { werk, } \\
\text { nooit-altijd } \\
(I-3)\end{array}$ & $\begin{array}{l}\text { Cognitief } \\
\text { zwaar } \\
\text { werk: con- } \\
\text { centratie } \\
\text { \& naden- } \\
\text { ken nodig, } \\
\text { nooit- } \\
\text { altijd (I-3) }\end{array}$ & $\begin{array}{l}\text { Werk- } \\
\text { druk, } \\
\text { nooit- } \\
\text { altijd } \\
\text { (I-3) }\end{array}$ & $\begin{array}{l}\text { Werk } \\
\text { belem- } \\
\text { merd } \\
\text { door } \\
\text { onnodige } \\
\text { admini- } \\
\text { stratie, } \\
\text { nooit- } \\
\text { dageliiks } \\
(1-4)\end{array}$ & $\begin{array}{l}\text { Emotio- } \\
\text { neel } \\
\text { zwaar } \\
\text { werk, } \\
\text { nooit- } \\
\text { vaakl } \\
\text { altijd } \\
(I-3)\end{array}$ & $\begin{array}{l}\text { Intimida- } \\
\text { tie, agres } \\
\text { sie, pes- } \\
\text { ten door } \\
\text { klanten, } \\
\text { nooit-een } \\
\text { enkele } \\
\text { keer of } \\
\text { vaker } \\
(0-1)\end{array}$ \\
\hline $\begin{array}{l}\text { Gemeenten \& } \\
\text { provincies }\end{array}$ & 2,13 & 2,14 & $\mathrm{I}, 64 \boldsymbol{\Delta}$ & 1,76 & 1,70 & 0,27 \\
\hline Ministeries & 2,01 & 2,08 & $\mathrm{I}, 6 \mathrm{I}$ & $1,80 \boldsymbol{\Delta}$ & 1,64 & $0, I I \square$ \\
\hline $\begin{array}{l}\text { Justitie, excl. } \\
\text { ministerie }\end{array}$ & $2,15 \boldsymbol{\Delta}$ & $2,27 \boldsymbol{\Delta}$ & $\mathrm{I}, 58 \square$ & $\mathrm{I}, 72$ & $\mathrm{I}, 88$ & $0,38 \boldsymbol{\Delta}$ \\
\hline Politie & $2,29 \boldsymbol{\Delta}$ & 2,14 & $1,68 \boldsymbol{\Delta}$ & $2,46 \boldsymbol{\Delta}$ & $2,06 \boldsymbol{\Delta}$ & $0,54 \boldsymbol{\Delta}$ \\
\hline $\begin{array}{l}\text { Rest publieke } \\
\text { sector }\end{array}$ & $2,19 \boldsymbol{\Delta}$ & 2,16 & 1,62 & $\mathrm{I}, 77$ & 1,79 & 0,23 \\
\hline Gemiddelde NL & 2,06 & 2,05 & $\mathrm{I}, 64$ & 1,55 & 1,66 & 0,23 \\
\hline
\end{tabular}

$\Delta$ Sectoren die deel uitmaken van de hoogst scorende homogene subset van sectoren; $\square$ Sectoren die deel uitmaken van de laagst scorende homogene subset van sectoren (beide volgens de Duncan-toets in One way variantieanalyses, $\mathrm{P}<, 00 \mathrm{I}$ ).

Overduidelijk blijkt dat de mentale belasting in de publieke sectoren over de hele linie groter is dan in de private sectoren (zie tabel 4a). Het onderwijs, de zorg, justitie en politie en de zakelijke en financiële dienstverlening scoren het hoogst op dit type belasting. Het creatieve werk in deze sectoren vergt veel concentratie en nadenken en vindt plaats onder werkdruk (want anders zouden deze drie kenmerken niet samenvallen onder één factor). Daarnaast zal het 'werken met mensen' in het onderwijs, de zorg en bij de politie debet zijn aan de mentaal-emotionele belasting. Binnen de private sectoren komen alleen de zakelijke en financiële dienstverlening in de buurt van de publieke sectoren.

De administratieve druk, waarvoor de laatste jaren extra aandacht is in het beleid, wordt het sterkst gevoeld door de politie, het onderwijs en de ministeries. Maar administratieve druk is niet uniek voor het publieke domein; ook bij de financiële instellingen wordt die druk als hoog ervaren.

Intimidatie en agressie loopt tot op grote hoogte parallel met de emotionele belasting. De politie, de zorg en het basis- en voortgezet onderwijs melden deze kanten van het werk het meest.

Bij de thema's fysieke belasting, gevaarlijk werk en afwijkende werktijden (samen één factor vormend, zie tabel 3) en de thema's arbeidscontract, arbeidsduur en autonomie op het werk (ook samen één factor vormend, zie eveneens tabel 3) slaat het beeld om. Het verschil tussen de publieke en private sectoren is op deze kenmerken minder groot (zie tabel $4 \mathrm{~b}$ ). Maar daar waar significante verschillen worden waargenomen, zijn die meer in het nadeel van de private sectoren. Daar is 
namelijk de fysieke belasting en de mate van gevaar op het werk significant groter.

Tabel 4b Gemiddelde scores van de 20 sectoren op fysieke belastingaspecten, werktijden en arbeidscontract $(n=20.638)$

\begin{tabular}{|c|c|c|c|c|c|c|}
\hline $\begin{array}{l}\text { Bedrijfs- } \\
\text { sectoren }\end{array}$ & $\begin{array}{l}\text { Fysiek } \\
\text { zwaar } \\
\text { werk: } \\
\text { nee- } \\
\text { soms- } \\
\text { regelma- } \\
\text { tig (I-3) }\end{array}$ & $\begin{array}{l}\text { Gevaarlijk } \\
\text { werk: nee- } \\
\text { soms- } \\
\text { regelma- } \\
\text { tig (I-3) }\end{array}$ & $\begin{array}{l}\text { Ploeg, } \\
\text { avond/ } \\
\text { nacht, } \\
\text { weekend: } \\
\text { nee- } \\
\text { soms- } \\
\text { regelma- } \\
\text { tig }(I-3)\end{array}$ & $\begin{array}{l}\text { Vast con- } \\
\text { tract/uit- } \\
\text { zicht op } \\
\text { vast vs. tij- } \\
\text { delijk/uit- } \\
\text { zend/ } \\
\text { oproep/ } \\
\text { inval (0-I) }\end{array}$ & $\begin{array}{l}\text { Aantal } \\
\text { con- } \\
\text { tract- } \\
\text { uren } \\
\text { per } \\
\text { week }\end{array}$ & $\begin{array}{l}\text { Auto- } \\
\text { nomie, } \\
\text { nee-son } \\
\text { meestal } \\
(1-3)\end{array}$ \\
\hline \multicolumn{7}{|l|}{ Privaat } \\
\hline Industrie & $1,64 \boldsymbol{\Delta}$ & $\mathrm{I}, 4 \mathrm{I}$ & 1,66 & $0,09 \square$ & $35,3 \wedge$ & 2,52 \\
\hline Bouw & $1,87 \boldsymbol{\Delta}$ & $1,54 \boldsymbol{\Delta}$ & $\mathrm{I}, 28 \square$ & $0,07 \square$ & $37,4 \boldsymbol{\Lambda}$ & 2,62 \\
\hline Handel & $1,57 \boldsymbol{\Delta}$ & 1,20 & I,74 $\Delta$ & $0,17 \Delta$ & 26,8 & 2,37 \\
\hline $\begin{array}{l}\text { Vervoer \& com- } \\
\text { municatie }\end{array}$ & I,54 $\Delta$ & 1,37 & $1,80 \Delta$ & $0,12 \Delta$ & 33,2 & $2,26 \square$ \\
\hline $\begin{array}{l}\text { Financiële instel- } \\
\text { lingen }\end{array}$ & $\mathrm{I}, 04 \square$ & $\mathrm{I}, 02 \square$ & $\mathrm{I}, 35 \square$ & $0,07 \square$ & $33,5 \Delta$ & 2,61 \\
\hline $\begin{array}{l}\text { Zakelijke dienst- } \\
\text { verlening }\end{array}$ & $\mathrm{I}, 06 \square$ & $\mathrm{I}, 05 \square$ & $\mathrm{I}, 45$ & $0,07 \square$ & $35,0 \wedge$ & $2,76 \Delta$ \\
\hline $\begin{array}{l}\text { Cultuur, sport, } \\
\text { recreatie, etc. }\end{array}$ & $\mathrm{I}, 38$ & 1,20 & I,76 $\Delta$ & $0,16 \Delta$ & 27,7 & 2,57 \\
\hline $\begin{array}{l}\text { Landbouw, bos- } \\
\text { bouw, visserij }\end{array}$ & $1,86 \boldsymbol{\Delta}$ & $1,46 \Delta$ & $|, 5|$ & $0,16 \Delta$ & 29,8 & $2,36 \square$ \\
\hline Horeca & $\mathrm{I}, 53 \boldsymbol{\Delta}$ & I,27 & $2,16 \Delta$ & $0,38 \Delta$ & $22,2 \square$ & $2,24 \square$ \\
\hline $\begin{array}{l}\text { Energie, water \& } \\
\text { overige bedrijven }\end{array}$ & $\mathrm{I}, 46$ & $\mathrm{I}, 27$ & $\mathrm{I}, 57$ & $0,12 \Delta$ & 30,7 & 2,46 \\
\hline \multicolumn{7}{|l|}{ Publiek } \\
\hline $\begin{array}{l}\text { Basis- \& speciaal } \\
\text { onderwijs }\end{array}$ & 1,25 & $\mathrm{I}, 07 \square$ & $\mathrm{I}, 23 \square$ & $0,05 \square$ & 28,5 & 2,44 \\
\hline $\begin{array}{l}\text { Voortgezet } \\
\text { onderwijs }\end{array}$ & 1,18 & I,II $\square$ & $\mathrm{I}, 36 \square$ & $0,04 \square$ & 30,4 & 2,46 \\
\hline Hoger onderwijs & $\mathrm{I}, 10 \square$ & $\mathrm{I}, 06 \square$ & $\mathrm{I}, 46$ & $0,13 \Delta$ & 31,3 & $2,74 \Delta$ \\
\hline Ziekenhuizen etc. & $\mathrm{I}, 50$ & 1,39 & I,78 $\Delta$ & $0,10 \square$ & 27,2 & 2,38 \\
\hline $\begin{array}{l}\text { Verpleeg- en } \\
\text { verzorgingshuizen }\end{array}$ & $1,62 \Delta$ & 1,28 & $1,84 \boldsymbol{\Lambda}$ & $0,14 \Delta$ & $23,4 \square$ & 2,37 \\
\hline $\begin{array}{l}\text { Gemeenten \& } \\
\text { provincies }\end{array}$ & 1,20 & 1,22 & $\mathrm{I}, 37$ & $0,04 \square$ & 32,7 & $2,7 \mid \Delta$ \\
\hline Ministeries & 1,22 & 1,25 & 1,39 & $0,06 \square$ & $35,4 \boldsymbol{\Lambda}$ & $2,66 \Delta$ \\
\hline $\begin{array}{l}\text { Justitie, excl. } \\
\text { ministerie }\end{array}$ & $\mathrm{I}, \mathrm{II} \square$ & $1,49 \Delta$ & 1,61 & $0,04 \square$ & 33,1 & 2,48 \\
\hline Politie & 1,33 & $2,03 \Delta$ & $2,23 \boldsymbol{\Delta}$ & 0,04 口 & $34,4 \boldsymbol{\Delta}$ & 2,43 \\
\hline
\end{tabular}


Tabel $4 b \quad$ (Vervolg)

\begin{tabular}{|c|c|c|c|c|c|c|}
\hline $\begin{array}{l}\text { Bedrijfs- } \\
\text { sectoren }\end{array}$ & $\begin{array}{l}\text { Fysiek } \\
\text { zwaar } \\
\text { werk: } \\
\text { nee- } \\
\text { soms- } \\
\text { regelma- } \\
\text { tig (I-3) }\end{array}$ & $\begin{array}{l}\text { Gevaarlijk } \\
\text { werk: nee- } \\
\text { soms- } \\
\text { regelma- } \\
\text { tig (I-3) }\end{array}$ & $\begin{array}{l}\text { Ploeg, } \\
\text { avond/ } \\
\text { nacht, } \\
\text { weekend: } \\
\text { nee- } \\
\text { soms- } \\
\text { regelma- } \\
\text { tig (I-3) }\end{array}$ & $\begin{array}{l}\text { Vast con- } \\
\text { tract/uit- } \\
\text { zicht op } \\
\text { vast vs. tij- } \\
\text { delijk/uit- } \\
\text { zend/ } \\
\text { oproep/ } \\
\text { inval (0-I) }\end{array}$ & $\begin{array}{l}\text { Aantal } \\
\text { con- } \\
\text { tract- } \\
\text { uren } \\
\text { per } \\
\text { week }\end{array}$ & $\begin{array}{l}\text { Auto- } \\
\text { nomie, } \\
\text { nee-soms- } \\
\text { meestal } \\
(I-3)\end{array}$ \\
\hline $\begin{array}{l}\text { Rest publieke } \\
\text { sector }\end{array}$ & 1,25 & $\mathrm{I}, 3 \mathrm{I}$ & $\mathrm{I}, 48$ & $0,13 \triangle$ & 33,0 & $2,63 \Delta$ \\
\hline Gemiddelde NL & 1,45 & 1,28 & 1,63 & 0,12 & 30,6 & 2,49 \\
\hline
\end{tabular}

$\boldsymbol{\Delta}$ Sectoren die deel uitmaken van de hoogst scorende homogene subset van sectoren; $\square$ Sectoren die deel uitmaken van de laagst scorende homogene subset van sectoren (beide volgens de Duncan-toets in One way variantieanalyses, $\mathrm{p}<, 00 \mathrm{I}$ ).

Ook worden flexibele contracten in de private sector gemiddeld meer toegepast (13\% versus $10 \%$ ) en zijn de werktijden er gemiddeld wat langer (31,7 uur versus 28,4 uur). Flexwerk komt veruit het meest voor in de horeca (38\% van de werknemers werkt daar met een flexcontract). Het aantal contracturen is het langst in de bouw, de industrie en bij de ministeries. Autonomie in het werk is het grootst in de zakelijke dienstverlening, het hoger onderwijs, de gemeenten, provincies en de ministeries. Autonomie is het laagst in de horeca, het vervoer, de landbouw en de handel. Ook de zorgsectoren scoren laag op autonomie in het werk. Strikt na te leven regels en procedures zullen in de zorg mede debet zijn aan die lage score.

Ten derde worden de arbeidsonzekerheid en de zogeheten effectvariabelen (burnout, vertrekwens, salaris- en arbeidstevredenheid) onder de loep genomen, zie tabel 4c. Bedrijfsinkrimping en arbeidsonzekerheid komen zowel in enkele private als enkele publieke sectoren meer dan gemiddeld voor. Het gaat hier met name om de financiële en zakelijke dienstverlening aan de private kant en de ministeries, politie en justitie aan de publieke kant. Het is goed om ons hier te realiseren dat de data in 2010 verzameld zijn, dus twee jaar na het begin van de kredietcrisis. Pogingen om tot personele krimp te komen vanwege noodzakelijke bezuinigingen worden hier dus zichtbaar. Hieraan valt toe te voegen dat er na 2010 nog forse bezuinigingen in de publieke sector doorgevoerd zijn. De effecten daarvan zullen in 2012 en later merkbaar worden.

Gevoelens van burn-out komen veruit het meest voor in de drie onderwijssectoren, zie tabel 4c. Toch is de vertrekwens daar niet evenredig groot. Die wens om ander werk te zoeken wordt namelijk sterker aangetroffen in een aantal private sectoren (horeca, handel, zakelijke dienstverlening) dan in het onderwijs.

De salaristevredenheid is het grootst in de financiële dienstverlening, het hoger onderwijs en de ministeries. Bij de politie en in de horeca is de salaristevredenheid het laagst. De arbeidstevredenheid in het algemeen is het hoogst in de publieke sector. Daarbinnen springen het hoger onderwijs, de gezondheidszorg, gemeenten \& provincies en justitie erboven uit. 
Tabel 4c Gemiddelde scores van de 20 sectoren op arbeidsonzekerheid en arbeidstevredenheid $(n=20.638)$

\begin{tabular}{|c|c|c|c|c|c|c|}
\hline $\begin{array}{l}\text { Bedrijfs- } \\
\text { sectoren }\end{array}$ & $\begin{array}{l}\text { Inkrimping } \\
\text { met/zonder } \\
\text { gedwongen } \\
\text { ontslagen, } \\
\text { niet-wel } \\
(0-I)\end{array}$ & $\begin{array}{l}\text { Werk- } \\
\text { onzeker- } \\
\text { heid, } \\
\text { nee-ja } \\
(0-I)\end{array}$ & $\begin{array}{l}\text { Gevoelens } \\
\text { van burn- } \\
\text { out, nooit- } \\
\text { dagelijks } \\
(I-7)\end{array}$ & $\begin{array}{l}\text { Ver- } \\
\text { trek- } \\
\text { wens, } \\
\text { nee-ja } \\
(0-1)\end{array}$ & $\begin{array}{l}\text { Salaris } \\
\text { tevre- } \\
\text { denheid } \\
(I-3)\end{array}$ & $\begin{array}{l}\text { Arbeids- } \\
\text { tevreden- } \\
\text { heid, onte- } \\
\text { vreden- } \\
\text { tevreden } \\
(I-5)\end{array}$ \\
\hline \multicolumn{7}{|l|}{ Privaat } \\
\hline Industrie & 0,26 & 0,32 & $2,06 \square$ & 0,33 & 1,95 & $3,82 \square$ \\
\hline Bouw & 0,26 & 0,30 & $\mathrm{I}, 90 \square$ & $0,21 \square$ & 1,91 & 3,86 \\
\hline Handel & $0,15 \square$ & $0,26 \square$ & $\mathrm{I}, 92 \square$ & 0,39 & $\mathrm{I}, 84 \square$ & $3,82 \square$ \\
\hline $\begin{array}{l}\text { Vervoer \& com- } \\
\text { municatie }\end{array}$ & 0,29 & 0,33 & $2,01 \square$ & $0,31 \square$ & 1,93 & $3,83 \square$ \\
\hline $\begin{array}{l}\text { Financiële instel- } \\
\text { lingen }\end{array}$ & $0,38 \Delta$ & $0,40 \Delta$ & $2,06 \square$ & 0,33 & $2,12 \Delta$ & 3,89 \\
\hline $\begin{array}{l}\text { Zakelijke dienst- } \\
\text { verlening }\end{array}$ & $0,31 \Delta$ & 0,31 & $2,10 \square$ & 0,40 & 1,96 & 3,90 \\
\hline $\begin{array}{l}\text { Cultuur, sport, } \\
\text { recreatie, etc. }\end{array}$ & $0,18 \square$ & 0,35 & $\mathrm{I}, 95 \square$ & 0,36 & $\mathrm{I}, 83 \square$ & $3,83 \square$ \\
\hline $\begin{array}{l}\text { Landbouw, bos- } \\
\text { bouw, visserij }\end{array}$ & $0,10 \square$ & $0,21 \square$ & $\mathrm{I}, 89 \square$ & $0,30 \square$ & 1,93 & 3,89 \\
\hline Horeca & $0,13 \square$ & $0,27 \square$ & $2,00 \square$ & $0,51 \Delta$ & $\mathrm{I}, 83 \square$ & $3,78 \square$ \\
\hline $\begin{array}{l}\text { Energie, water \& } \\
\text { overige bedrijven }\end{array}$ & $0,18 \square$ & 0,30 & $2,03 \square$ & 0,34 & 1,92 & $3,84 \square$ \\
\hline \multicolumn{7}{|l|}{ Publiek } \\
\hline $\begin{array}{l}\text { Basis- \& speciaal } \\
\text { onderwijs }\end{array}$ & 0,22 & $0,18 \square$ & $2,28 \Delta$ & $0,28 \square$ & $\mathrm{I}, 84 \square$ & $3,96 \Delta$ \\
\hline $\begin{array}{l}\text { Voortgezet } \\
\text { onderwijs }\end{array}$ & $0,15 \square$ & $0,19 \square$ & $2,39 \boldsymbol{\Delta}$ & $0,29 \square$ & $\mathrm{I}, 84 \square$ & 3,91 \\
\hline Hoger onderwijs & 0,24 & $0,24 \square$ & $2,14 \Delta$ & 0,33 & $2,02 \Delta$ & $4,03 \Delta$ \\
\hline $\begin{array}{l}\text { Ziekenhuizen \& } \\
\text { rest gezondheids- } \\
\text { zorg }\end{array}$ & 0,20 & $0,21 \square$ & $2,08 \square$ & $0,29 \square$ & 1,89 & $3,97 \boldsymbol{\Lambda}$ \\
\hline $\begin{array}{l}\text { Verpleeg- en } \\
\text { verzorgingshuizen }\end{array}$ & 0,21 & $0,23 \square$ & $2,01 \square$ & 0,32 & $\mathrm{I}, 87$ & 3,91 \\
\hline $\begin{array}{l}\text { Gemeenten \& } \\
\text { provincies }\end{array}$ & 0,23 & 0,32 & $2,07 \square$ & 0,33 & 1,98 & $3,93 \wedge$ \\
\hline Ministeries & $0,35 \Delta$ & $0,46 \Delta$ & $2,03 \square$ & 0,34 & $2,01 \Delta$ & 3,91 \\
\hline $\begin{array}{l}\text { Justitie, excl. } \\
\text { ministerie }\end{array}$ & $0,33 \wedge$ & 0,33 & $\mathrm{I}, 98 \square$ & $0,29 \square$ & 1,93 & $3,96 \wedge$ \\
\hline Politie & $0,30 \Delta$ & $0,24 \square$ & $\mathrm{I}, 97 \square$ & $0,26 \square$ & $\mathrm{I}, 74 \square$ & 3,85 \\
\hline $\begin{array}{l}\text { Rest publieke } \\
\text { sector }\end{array}$ & 0,28 & 0,33 & $2,06 \square$ & 0,34 & 1,99 & $3,94 \boldsymbol{\Delta}$ \\
\hline Gemiddelde NL & 0,23 & 0,29 & 2,04 & 0,34 & 1,92 & 3,87 \\
\hline
\end{tabular}


Figuur 1 Plaatsing van de 20 sectoren op twee assen (bron: NEA 2010; $n=18.734$ )

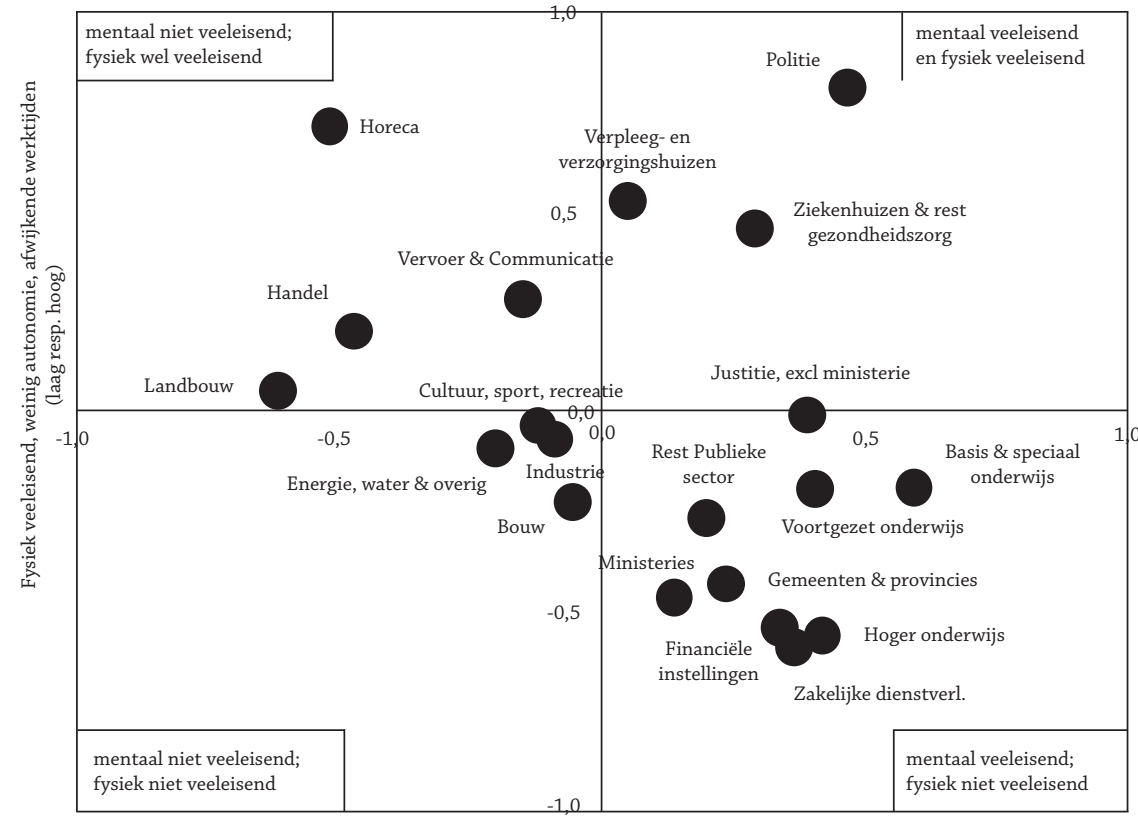

Gevarieerd, maar mentaal-emotioneel veeleisend werk (laag resp. hoog)

$\Delta$ Sectoren die deel uitmaken van de hoogst scorende homogene subset van sectoren; $\square$ Sectoren die deel uitmaken van de laagst scorende homogene subset van sectoren (beide volgens de Duncan-toets in One way variantieanalyses, $\mathrm{P}<, 00 \mathrm{I}$ ).

Er zijn nu 18 werkkenmerken van 10 private en 10 publieke sectoren de revue gepasseerd. Dat leidt tot behoefte aan comprimering. Om dat te bewerkstelligen is een factoranalyse uitgevoerd op alle 35 items van de 14 werkkenmerken, dus zonder opname van de 10 items die deel uitmaken van de vier 'effect-variabelen' (zie tabel 3). Het gaat hier dus puur om de werkkenmerken; kenmerken waarbij gezondheid en tevredenheid een rol spelen, zijn dus buiten deze factoranalyse gelaten. De factoranalyse (Principale Componenten Analyse met Varimax-rotatie) werd op dusdanige wijze uitgevoerd dat er twee 'gedwongen' factoren ontstonden. Deze twee factoren konden worden benoemd als (1) gevarieerd, maar mentaalemotioneel veeleisend werk, en (2) fysiek veeleisend werk, met weinig autonomie en in afwijkende werktijden. Vervolgens zijn aan elke respondent beide factorscores toegekend. Een factorscore heeft een gemiddelde waarde van 0 en een standaarddeviatie van 1 . Voorts is het eigene van de twee factorscores dat ze niet gecorreleerd zijn. Figuur 1 plaatst de 10 private en de 10 publieke sectoren door middel van deze twee dimensies op twee assen.

De twee dimensies combinerend ontstaan er vier kwadranten (zie figuur 1): 
Figuur 2 Werkkenmerken-profiel van de publieke sector als geheel (in Z-scores; $n=20.638$; bron: NEA 2010; het gemiddelde van alle publieke en private sectoren samen $=0$ )

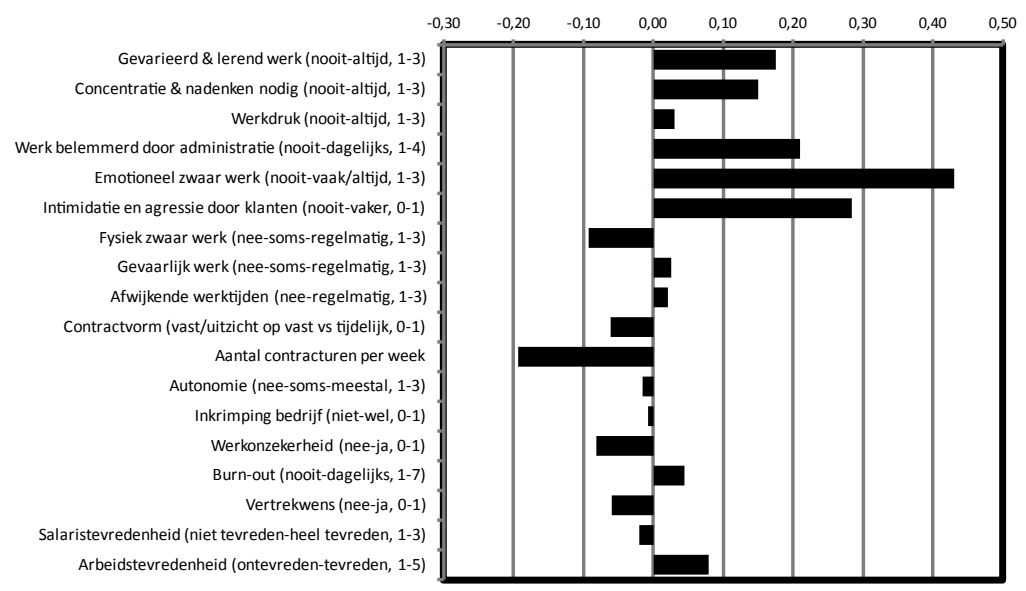

1 Rechtsboven: gevarieerd en mentaal-emotioneel veeleisend werk, tevens fysiek veeleisend werk. Hieronder horen politie, ziekenhuizen en verpleeg- en verzorgingshuizen. Dit zou als het 'risico-kwadrant' kunnen worden bestempeld; er is hier immers sprake van zowel mentaal-emotionele belasting als fysieke belasting.

2 Rechtsonder: gevarieerd en mentaal-emotioneel veeleisend werk, maar niet fysiek inspannend werk. Hierin komen alle drie de onderwijssectoren voor, naast ministeries, gemeenten \& provincies, de restgroep van de publieke sector, alsmede zakelijke en financiële dienstverlening.

3 Linksboven: weinig gevarieerd en mentaal-emotioneel veeleisend werk, maar wel fysiek veeleisend werk. Vier sectoren vallen in dit kwadrant: horeca, handel, vervoer \& communicatie en landbouw.

4 Linksonder: weinig gevarieerd en mentaal-emotioneel veeleisend werk, en ook weinig fysiek veeleisend werk. In dit kwadrant zijn nog net gesitueerd: industrie, bouw, sport, cultuur en recreatie en energie, water en overig; deze sectoren scoren dus nog net onder het gemiddelde op beide dimensies.

Hier wordt nog een tweede wijze van comprimering toegepast, die is toegespitst op de overall-verschillen tussen het private en het publieke domein (zie figuur 2). Daartoe is de score op alle 18 werkkenmerken van elke werknemer in de steekproef omgezet in een gestandaardiseerde score (ook wel Z-scores genoemd). Een gestandaardiseerde score geeft aan hoeveel standaarddeviaties de desbetreffende score van het gemiddelde af ligt. Het gemiddelde van een gestandaardiseerde score is gelijk aan nul. Het voordeel van de omzetting van de ongestandaardiseerde 'normale' scores in Z-scores is dat Z-scores van een individu of groep op meerdere kenmerken met elkaar vergeleken kunnen worden. Zo kan bijvoorbeeld 
arbeidsduur worden vergeleken met werkdruk, hoewel arbeidsduur uitgedrukt wordt in aantal werkuren per week en werkdruk in een score lopend van 1 tot en met 4 (nooit, soms, vaak, altijd). Door deze Z-scoretechniek is het mogelijk een profiel op te stellen van één sector of van alle private sectoren samen of alle publieke sectoren samen.

Figuur 2 geeft het werkkenmerken-profiel van de publieke sector als geheel weer, in vergelijking met alle private sectoren als geheel. De 0-lijn is dus het gemiddelde van alle 20 sectoren. In de figuur worden de gemiddelde gestandaardiseerde scores van de publieke sector op alle 18 werkkenmerken weergegeven. Het mag duidelijk zijn dat het beeld van de private sector het spiegelbeeld is van de publieke sector.

De verschillen tussen de Z-scores van de het private en het publieke domein zijn weer getoetst (met variantieanalyses). Alle verschillen tussen het publieke en het private domein zijn hoogst significant $(\mathrm{p}<, 001)$, behalve bij afwijkende werktijden $(\mathrm{p}<, 08)$, autonomie in het werk $(\mathrm{p}<, 02)$, bedrijfsinkrimping $(\mathrm{p}<, 33)$ en salaristevredenheid $(\mathrm{p}<, 02)$.

De publieke sector scoort gemiddeld het hoogst op de zes aspecten van mentale inspanning, op burn-out en op arbeidstevredenheid (zie figuur 2). En gemiddeld het laagst op fysiek zwaar werk, flexwerk, duur van de werkweek, werkonzekerheid en vertrekwens.

\section{Conclusie en discussie}

Voor de hier gerapporteerde analyses is gebruikgemaakt van een groot en representatief databestand, de Nationale Enquête Arbeidsomstandigheden 2010. Dat verhoogt ook de betrouwbaarheid en representativiteit van de resultaten. Uit de analyses - die zich richten op de vergelijking van 10 private en 10 publieke sectoren - blijkt dat in de publieke sectoren meer met vaste contracten gewerkt wordt en dat de duur van de werkweek korter is. Toch is de mentaal-emotionele belasting in de publieke sectoren over de hele linie groter dan in de private sectoren. Daarentegen komen fysieke belasting, gevaarlijk werk en afwijkende werktijden significant minder voor in de publieke sectoren. In 2010 komt arbeidsonzekerheid meer dan gemiddeld voor in de financiële en zakelijke dienstverlening en het vervoer, maar ook bij de ministeries, justitie en politie. Gevoelens van burn-out komen veruit het meest voor in de drie onderwijssectoren. De salaristevredenheid is het grootst in de financiële dienstverlening, het hoger onderwijs en de ministeries. Bij de politie en in de horeca is de salaristevredenheid het laagst. De arbeidstevredenheid is gemiddeld het hoogst in de publieke sectoren. Publieke sectoren en private sectoren kunnen ieder voor zich moeilijk als één geheel worden gezien. Ministeries, gemeenten \& provincies en hoger onderwijs lijken namelijk - wat arbeidsvoorwaarden en arbeidsomstandigheden betreft - sterk op de zakelijke en financiële dienstverlening. Maar basis- en voortgezet onderwijs, zorg en welzijn en politie verschillen sterk van de andere genoemde publieke sectoren.

Hoe verhouden onze resultaten zich met eerder onderzoek? De conclusie van Steijn en Groeneveld (2009), die zich baseren op BZK-data, dat de arbeidstevre- 
denheid in het publieke en private domein niet substantieel van elkaar verschillen, kunnen we met ons onderzoek niet onderschrijven. Wij vonden, zoals gezegd, dat de arbeidstevredenheid in de publieke sector gemiddeld het hoogst is. Daarbinnen springen het hoger onderwijs, de gezondheidszorg, gemeenten \& provincies en justitie er weer boven uit. Dit strookt met onderzoek uit de VS en Italië. De verhoudingsgewijs hoge arbeidstevredenheid van de werknemers in het Nederlandse publieke domein werd namelijk ook door DeSantis en Durst (1996) voor de Verenigde Staten en door Ghinetti (2007) voor Italië vastgesteld. Dat werknemers in het publieke domein meer autonomie in het werk hebben, hetgeen door Macklin et al. (2006) voor Australië werd geconcludeerd, kan in ons onderzoek niet worden bevestigd. Wij vinden namelijk geen significant verschil tussen het publieke en het private domein. Onze resultaten stroken ook niet met die van Steijn en Groeneveld (2009), die vaststelden dat in Nederland in het publieke domein grotere tevredenheid bestaat ten aanzien van zelfstandigheid en verantwoordelijkheid in het werk dan in het private domein. Het werkkenmerk autonomie en 'ruimte voor professionaliteit' (Pot, 2011) is groot in het hoger onderwijs, de ministeries, gemeenten \& provincies, maar - aan de andere kant - het grootst in de zakelijke dienstverlening.

Hoewel er voor dit artikel, vanwege het ontbreken van bevredigende onderzoeksliteratuur, geen expliciete hypothesen zijn geformuleerd, lopen we wel enkele in dagbladen en tijdschriften weergegeven uitspraken langs.

- Gemiddeld zijn de werkdruk en gevoelens van burn-out in de publieke sectoren, zoals in perspublicaties naar voren gebracht, inderdaad hoger dan in de private sectoren als geheel. Onze conclusie dat werkdruk in het publieke domein hoger is dan in het private domein, strookt ook met de conclusie van Steijn en Groeneveld (2009), die vaststellen dat de tevredenheid over de werkdruk in het publieke domein lager is dan in het private domein. De werkdruk is het hoogst in de drie onderwijssectoren, maar is ook hoog in de horeca en de financiële en zakelijke dienstverlening. De daaraan verwante burn-outverschijnselen komen ook het meest voor in de drie onderwijssectoren, iets minder vaak in de gezondheidszorg en bij gemeenten \& provincies, maar ook bij de financiële en zakelijke dienstverlening. Vaak worden lange werkuren gekoppeld aan werkdruk en burn-out (uit onderzoek blijkt dat ook). Maar in de publieke sector is de werkweek gemiddeld korter dan in de private sector als geheel (28 uur versus 32 uur per week). Bij het leggen van een relatie tussen werktijd en werkdruk in de publieke sector is dus voorzichtigheid geboden.

- Ook gerelateerd aan de werkdruk is de administratieve druk, die in de publieke sectoren vaak wordt bekritiseerd. De data onderschrijven deze kritiek. De politie is hier met grote voorsprong de koploper. Daar wordt veruit het meest melding gemaakt van onnodige administratie. Maar ook in het onderwijs, de ministeries en de financiële sector vinden de werknemers vaak dat hun werk belemmerd wordt door onnodige administratie. Administratieve druk is dus niet per se voorbehouden aan de publieke sector.

- Het werkkenmerk intimidatie en agressie van klanten wordt - zoals verondersteld - twee keer zo vaak aangetroffen in de publieke sectoren dan in de 
private sectoren. In de publieke sectoren heeft gemiddeld $35 \%$ van de werknemers daar last van, in de private sectoren $17 \%$. De zorg, politie en justitie springen eruit.

- De werkonzekerheid is gemiddeld iets hoger in de private sectoren dan in de publieke sectoren. Toch is de werkonzekerheid - als naar de sectoren apart wordt gekeken - het hoogst bij de ministeries. Dreiging van personele ingrepen heeft dat gevoel in 2010 waarschijnlijk gevoed. Maar ook in de bankensector is de werkonzekerheid inmiddels hoog. Onderwijs en zorg behoren niet tot de sectoren waar de arbeidsonzekerheid hoog is; daar was in 2010 ook geen sprake van personele krimp. In 2011/2012 is er wel discussie ontstaan over personele krimp in het basisonderwijs.

- Gemiddeld verschillen de publieke en private sectoren weinig ten aanzien van salaristevredenheid. Weliswaar is de salaristevredenheid het hoogst bij de financiële instellingen, maar een aantal publieke sectoren (ministeries, gemeenten \& provincies, hoger onderwijs) volgen op de voet. Als er ergens sprake is van salarisontevredenheid, dan is dat wel bij de politie en in de horeca. Ook de werknemers in het basis- en voortgezet onderwijs zijn relatief ontevreden over hun salaris.

Alles bij elkaar worden de krantenberichten over de arbeidsomstandigheden en arbeidsvoorwaarden in de publieke sectoren in grote lijnen door de data onderstreept.

Het is relevant om te bezien in hoeverre de in tabel 1 vermelde sekse-, leeftijdsen opleidingskenmerken van de 20 sectoren gerelateerd zijn aan de kwaliteit van het werk van die sectoren. Er zijn twee sectoren met een hoog percentage jongeren in dienst: de handel en de horeca. Beide sectoren kenmerken zich door relatief veel flexwerk, deeltijdwerk, afwijkende werktijden, lichamelijk zwaar werk en licht werk uit mentaal oogpunt. Dat type werk wordt blijkbaar aan jongeren aangeboden. De arbeids- en salaristevredenheid is laag in beide sectoren en de vertrekwens is aan de hoge kant. Men mag dus aannemen dat veel jongeren handel en horeca niet zien als eindstation van hun arbeidzame leven. In het basisonderwijs en de zorgsectoren bestaat het personeelsbestand voor meer dan driekwart uit vrouwen. Uit de analyse van de werkkenmerken dringt echter niet één duidelijk gemeenschappelijk beeld op van deze 'vrouwelijke' onderwijs- en zorgsectoren. Wat men zou kunnen concluderen, is dat de mentale belasting in deze 'vrouwensector' aan de hoge kant is, met name de emotionele belasting door de intensieve 'klantcontacten', maar ook dat de werkzekerheid er groot is, de arbeidstevredenheid hoog is en de vertrekwens laag. Ten slotte kijken we naar de relatie tussen het opleidingsniveau en de werkkenmerken van de sectoren. De sectoren met veel hoger opgeleiden zijn de zakelijke en financiële dienstverlening, het onderwijs, ministeries, gemeenten \& provincies en justitie. Dit zijn ook de sectoren die in figuur 1 in het kwadrant mentaal veeleisend en fysiek niet-veeleisend terecht zijn gekomen. Genoemde sectoren worden over het algemeen gekenmerkt door creatief en cognitief zwaar werk met werkdruk, een hoge mate van autonomie, en vaste contracten met lange werktijden. 
Het antwoord op de mogelijk te stellen vraag of de publieke sectoren resp. de private sectoren als één geheel gezien kunnen worden, kan niet bevestigend worden beantwoord. Het hoger onderwijs, gemeenten \& provincies, justitie en ministeries lijken - wat arbeidsvoorwaarden en arbeidsomstandigheden betreft - sterk op de zakelijke en financiële dienstverlening. Andere delen van de publieke sector (basis- en voortgezet onderwijs, zorg en welzijn, politie) verschillen sterk van de hiervoor genoemde publieke sectoren. Vooral de - door de veeleisende klantcontacten bepaalde - emotionele belasting en het burn-out-risico zijn significant groter in het onderwijs, de zorg en de politie dan bij ministeries, gemeenten \& provincies. Bij ministeries is de personele krimp en de daaraan gekoppelde arbeidsonzekerheid tegenwoordig een belangrijk probleem.

\section{Literatuur}

Allington, N.F.B. \& Morgan, Ph.I. (2003). Does it pay to work in the public sector? Evidence from three decades of econometric analyses. Pubic Money \& Management, 23, 253-262.

Aryee, S. (1992). Public and private sector professionals: a comparative study of their perceived work experience. Group \& Organization Management, 17, 72-85.

Besten, H. den, Blatter, B. \& Smulders, P. (2009). Arbeidsomstandigheden en arbeidsmarkttekorten in onderwijs, zorg en welzijn. Tijdschrift voor Arbeidsvraagstukken, 25, 137-146.

Boyne, G., Jenkins, G. \& Poole, M. (1999). Human resources management in the public and private sectors: an empirical comparison. Public Administration, 77, 407-420.

Buelens, M. \& Broeck, H. van den (2007). An analysis of differences in work motivation between public and private sector organizations. Public Administration Review, 67, 65-74.

CAOP (Centrum Arbeidsverhoudingen Overheidspersoneel, red.) (2011). De staat van de ambtelijke dienst; hoe staan de ambtenaren er anno 2011 voor? Den Haag: CAOP.

Dagevos, J. (1995). Allochtonen bij de rijksoverheid; oorzaken voor het succes en het falen van voorkeursbeleid. Tijdschrift voor Arbeidsvraagstukken, 11, 143-145.

DeSantis, V.S. \& Durst, S.L. (1996). Comparing job satisfaction among public- and privatesector employees. The American Review of Public Administration, 26, 327-343.

Dhondt, S., Have, K. ten \& Kraan, K.O. (2010). Vijfentwintig jaar kostenbesparing bij de overheid; gevolgen voor de kwaliteit van de arbeid en productiviteit. In R. Batenburg, P. de Beer, J. Mevissen \& K. Tijdens (red.), Arbeid in crisis? (pp. 143-162). Den Haag: Boom Lemma uitgevers.

Dollard, M. \& Walsh, C. (1999). Illusory correlation: is work stress really worse in the public sector? Journal of Occupational Health and Safety, 15, 219-229.

Elliott, R.F. \& Murphy, P.D. (1987). The relative pay of public and private sector employees, 1970-1984. Cambridge Journal of Economics, 11, 107-132.

Freese, C., Heinen, J. \& Schalk, R. (1999). Organisatieverandering en het psychologisch contract, betrokkenheid en intentie tot verloop bij werknemers in de thuiszorg. Tijdschrift voor Arbeidsvraagstukken, 15, 208-218.

Ghinetti, P. (2007). The public-private job satisfaction differential in Italy. Labour, 21, 361-388.

Hoek, P. van der (1989). Pay differentials between the private and the public sector in the Netherlands. Public Finance Review, 17, 84-95. 
Houtman, I.L.D. \& Bossche, S.N.J. van den (2010). Trends in de kwaliteit van de arbeid in Nederland en Europa. Tijdschrift voor Arbeidsvraagstukken, 26, 432-450.

Houtman, I.L.D, Smulders, P.G.W. \& Klein Hesselink, D.J. (2004). Trends in arbeid 2004. Hoofddorp: TNO Arbeid.

Koppes, L., Vroome, E. de, Mol, M., Janssen, B. \& Bossche, S. van den (2011) Nationale Enquête Arbeidsomstandigheden 2010; methodologie en globale resultaten. Hoofddorp: TNO.

Lyons, S.T., Duxbury, L.E. \& Higgins, Ch.A. (2006). A comparison of the value and commitment of private sector, public sector and parapublic sector employees. Public Administration Review, 66, 605-618.

Macklin, D.S., Smith, L.A \& Dollard, M.F. (2006). Public and private work stress: worker compensation, levels of distress and job satisfaction, and the demand-control-support model. Australian Journal of Psychology, 58, 130-143.

Midttun, L. (2007). Private or public? An empirical analysis of the importance of work values for work sector choice among Norwegian medical specialists. Social Science and Medicine, 64, 1265-1277.

Miller, M.A. (1996). The public-private pay debate: what do the data show? Monthly Labor Review, 119, 18-29.

Moree, M. \& Vulto, M. (1995). Zorgarbeid als zorgenkind? De kwaliteit van de arbeid in de gezinsverzorging. Tijdschrift voor Arbeidsvraagstukken, 11, 48-59.

Pillay, R. (2009). Work satisfaction of professional nurses in South Africa: a comparative analysis of the public and private sectors. Human Resources for Health, 7, article number 15 .

Pot, F.D. (2011). Productiviteit en ruimte voor professionaliteit. In CAOP (Centrum Arbeidsverhoudingen Overheidspersoneel, red.). De staat van de ambtelijke dienst: hoe staan de ambtenaren er anno 2011 voor? (pp. 36-40). Den Haag: CAOP.

Steijn, B. (2008). Person-environment fit and public service motivation. International Public Management Journal, 11, 13-27.

Steijn, B. \& Groeneveld, S. (2009). Strategisch HRM in de publieke sector. Assen: Van Gorcum.

Wal, Z. van der, Graaf, G. de \& Lasthuizen, K. (2008). What's valued most? Similarities and differences between the organizational values of the public and the private sector. Public Administration, 86, 465-482.

Wal, Z. van der \& Huberts, L. (2008). Value solidity in government and business: results of an empirical study on public and private sector organizational values. The American Review of Public Administration, 38, 264-285.

Willem, A., Vos, A. de \& Buelens, M. (2010). Comparing private and public sector employees' psychological contracts, do they attach equal importance to generic work aspects? Public Management Review, 12, 275-302.

Zeffane, R. (1994). Patterns of organizational commitment and perceived management style: a comparison of public and private sector employees. Human Relations, 47, 977-993. 